\title{
Stages in the configuration of urban form in urban development planning: the emerging role of open spaces as sustainability mechanism. The case of Valladolid (Spain)
}

\author{
Miguel Fernández-Maroto \\ Instituto Universitario de Urbanística, Universidad de Valladolid. Valladolid, Spain \\ E-mail:miguel@institutourbanistica.com
}

\begin{abstract}
Along the last five decades and through three different stages, the urban development plans - general plans - of Valladolid, a medium-sized Spanish city, show an interesting evolution in the way of configuring the global urban form and controlling urban development that we can also find in other similar Spanish cities. In the sixties and seventies, plans proposed 'autonomous' expansive schemes foreseeing a huge rate of urban growth, so they defined wide areas to be urbanised through new transport infrastructures and typical zoning mechanisms. In the eighties, after decay in urban and economic development and during the transition to democracy, the new local governments focused on the existing city and fostered a more controlled urban growth. However, plans continued to employ the same tools to manage future urban form - definition of transport infrastructures and sectors to be urbanised-, although they looked for more 'controllable' forms, such as radio-concentric ones, aiming at a gradual and homogeneous implementation - compact city-. When real-estate market recovered in early nineties, this strategy revealed its weaknesses: fragmented urban fringe and tendency to a congestive model, reinforced when a new generation of expansive plans drove these schemes out of the limits they were conceived with. However, an alternative and more sustainable model had already emerged, as some new urban planning tools proposed a change of perspective: managing global urban form not through future urbanised spaces, but through open ones, generating an 'empty'network able to give coherence to the whole urban structure in a metropolitan scale.
\end{abstract}

\section{Keywords: Urban development planning, urban model, open} spaces, Valladolid, Spain

\section{Introduction}

The term of 'urban morphology' is related to different urban research traditions. One of the most influential is the Conzenian school, whose antecedents are the work of some German geographers at the end of nineteenth century. Their starting point was 'the scope that existed for recognizing within town plans the stages in their development' (Whitehand, 2001, p. 104). That approach concerns town plans understood as the result of different urban processes of both growing and transformation, whether these processes were planned or not.

M. R. G. Conzen developed this approach through new concepts such as urban fringe or morphological frame. The latter relates to the morphogenesis, specifically during the transformation of rural land to urban tissues. The forms that are created at that time show 'a powerful long-term influence'; 'town plans are powerful influences on future forms, with residual features being passed down through successive generations of society, often over very lengthy periods' (Whitehand, 2001, p. 106).

Considering these processes of generation of new urban spaces, they can also appeal to town plans understood not as a result, but as a project. Urban development planning deals 
precisely with the transformation of non-urban areas into urban ones, proposing a more or less defined form, according to their scope. These forms that plans propose are the result of different influences and, as pointed, they are themselves a powerful influence, even though the plan is revised or substituted by a new one before becoming the real town plan. Thus, it is also possible and very interesting to analyse the stages in the configuration of urban form in urban development planning, comprising the characterization of the influences affecting every stage and the influence of every of them in the next ones. Following the Conzenian term, this paper aims at defining successive 'morphological periods' in urban development planning in the Spanish city of Valladolid.

Regarding this aim, it is first necessary to set the concept of urban development planning, as it comprises a wide range of planning tools with very different scopes. This paper focus on urban development planning tools whose scope comprises the whole city, namely planning tools defining the global urban form. Thus, it concentrates on urban structure and the way it is defined rather than on typological analysis. In the Spanish case, this kind of tools corresponds to the so-called Planes Generales de Ordenación Urbana or general plans, whose main objective has consisted of planning the urban development of the whole city, defining those areas to be urbanised in the short and in the long term along with the structure supporting this growth.

Second, it is also necessary to justify why Valladolid has been chosen as case. Valladolid is a medium-sized city located in the centre of the region of Castilla y Léon, in the north-west of inner Spain, and along the last five decades, it has experienced an impressive urban growth. At the end of the fifties it had only 150,000 inhabitants, and it is now the centre of a metropolitan area with 400,000 inhabitants, three quarters of them corresponding to the city. This growth was to be managed through different general plans; among them, two comprising the city and two comprising both the city and its metropolitan area can be highlighted. Beyond its specific characteristics and proposals, these plans represent the trends in Spanish urban planning along this period to be also found in other similar Spanish cities. Regarding urban form configuration, they define three clear stages that could be explained as the evolution of general plans towards more place-based proposals.

\section{The sixties and seventies: autonomous schemes for an expansive urban growth}

Form early sixties, Spanish economy experienced an impressive growth that was accompanied by a huge urban growth. In fact, a clear connection was established by the politicians between both phenomena, so it was stated that urban growth would reinforce economic growth. Consequently, the Spanish government promoted an expansive urban policy that required a new generation of urban planning tools.

The first Spanish Land Property and Urban Planning Act had been approved in 1956. This act created the general plans as the main tool within urban law in charge to plan urban growth in every municipality. These plans were to be coordinated at a provincial and even national level, and were also to de developed through other planning tools affecting sectors to be urbanised or transformed. However, the implementation of this act was slow and partial. Some municipalities approved their general plans, but they continued to follow schemes and to use mechanisms that they had been using since nineteenth century. The Ministry of Housing, created in 1957 to assume all competences concerning urban planning and development, decided to act by itself and it developed a lot of urban projects even though the general plans of the municipalities had not included them. At the same time, it put pressure on municipalities so they approved new general plans fostering urban growth.

The case of Valladolid is very representative of this process. During the sixties, the population grew more than $50 \%$ and that involved a remarkable urban transformation. A lot of neighbourhoods became densified and new residential zones for workers were built in some little vacant spaces among them. This transformation was mainly controlled by local real estate developers supported by the 


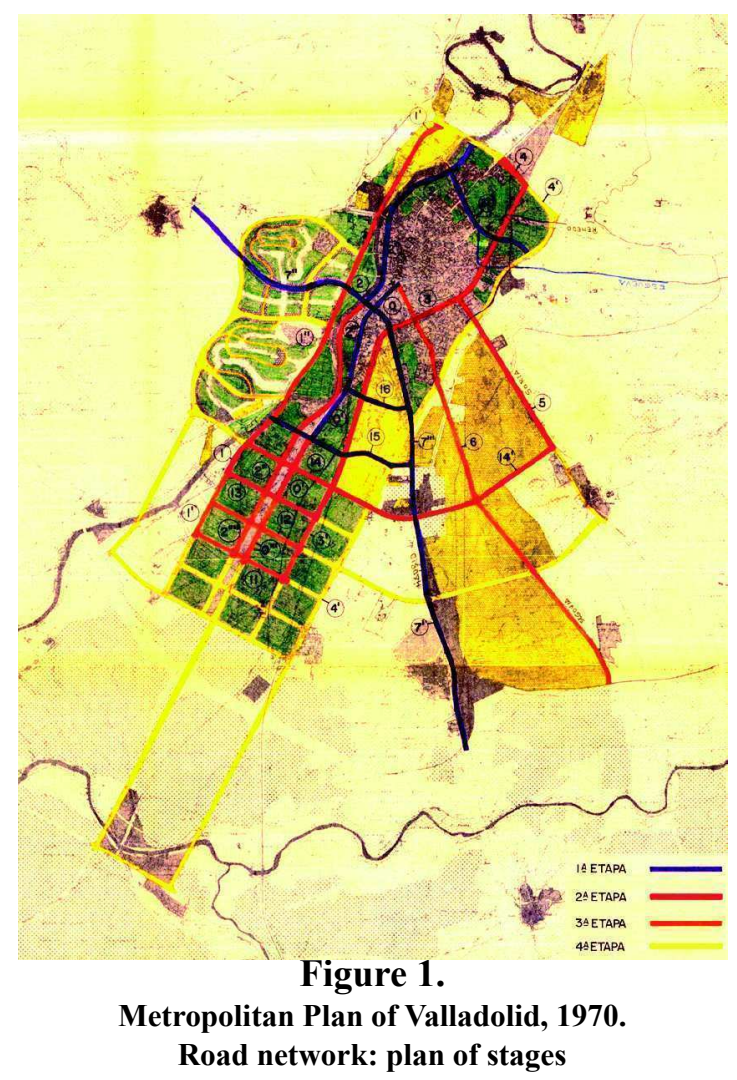

municipal government, which was reluctant to update the obsolete urban plan that had been approved in 1939. However, at the end of this decade, when these local developers were also looking for new ways of getting profits from urban growth, the local government finally accepted the suggestion of the Ministry of Housing to elaborate a new general plan.

At that moment, the Directorate-General for Urbanism was also looking for new ways of configuring urban growth. Most general plans that had been approved until then were rather traditional plans of expansion through ensanches, but that did not satisfy the requirements of the great urban growth that Spanish cities were experiencing. Rejecting the typical monocentric model, the 'directional growth' became the best solution (Terán, 1982, p. 402-3). This new urban model came from the theories developed by C. A. Doxiadis, widely spread in Spain. This famous Greek architect defended that the traditional urban model, composed of centre and periphery, was no longer viable due to the expansion of cities. He then proposed the alternative of the 'dynapolis', so 'the modern metropolis can expand following a direction [...] centre and periphery would keep a continuous balance while the city grows over vacant or uninhabited spaces' (Doxiadis, 1963, p. 112).

Regarding this new orientation of urban planning policies, the new general plan of Valladolid became 'the clearest example of directional planning, which has assumed the well-known proposals of Doxiadis' (Terán, 1982 , p. 403). In 1968, the local government of Valladolid commissioned a team leaded by the architect Javier de Mesones the elaboration of this new general plan, but the Ministry of Housing decided that this plan would include not only the municipality of Valladolid, but also other 13 municipalities around it, in order to promote urban development at a metropolitan scale. The general plan became then a metropolitan plan.

Doxiadis had explained that the dynapolis 'would progressively take its geometric form through a rectilinear system of axes', and that grid would be organised through the 'human sector', 'basic element of widest urban zones as a whole' (Doxiadis, 1963, p. 112-5). The new metropolitan plan, which was finally approved in 1970, clearly assumed these ideas. Taking into account that the workers neighbourhoods were mainly located along the north and the east of the city, the plan proposed to foster the urban growth towards the southwest, which was also the direction of the main transportation routes connecting with Madrid and the northwest of Spain. Following this direction, the plan designed an ambitious grid of motorways that extends beyond the limits of the municipality of Valladolid ignoring any territorial constraint and that defines residential sectors for 20,000 inhabitants, while new industrial zones are placed at the east, close to workers neighbourhoods.

New transportation infrastructures and typical zoning mechanisms define an urban model that matches Doxiadis ideas and that is also 'a faithful reflection of the urban planning policy, prevailing in the sixties, impelled by Local and Central Administrations' (Figueroa Salas, 2000, p. 52). There is not any reflection on existing urban conditions, but reports that analysed the opportunities to contribute to economic development through urban growth. Valladolid had 235,000 inhabitants at the 
beginning of the seventies, many of them living in bad conditions, but the metropolitan plan concentrated only on how to reach 780,000 inhabitants in 2003. Foreseeing this huge population growth, it proposed an 'autonomous' expansive scheme, an abstract and self-organised grid to make that growth possible. However, the economic crisis that burst just a few years later made this proposal unfeasible. Along with other factors, that resulted in a clear shift in urban policies that also affected the way to plan the urban form of the city.

\section{The eighties: a radio-concentric model for a compact city}

From the mid-seventies, Spain entered into a period of deep political and economic changes. The international crisis that burst in 1973 affected Spanish economy and stopped urban growth while the country was carrying out the transition to democracy after the death of dictator Franco in 1975. After the first democratic general election that took place in 1977 and once the new democratic Constitution was approved in 1978, the government called for the first municipal election on April 1979. Urban issues played a key role during that campaign. Left-wing parties such as the socialists or the communists pledged themselves to foster a radical shift in urban policies. They promised to focus on workers neighbourhoods, which were suffering severe deficits of basic urban equipment such as parks, schools, health centres, etc., and regarding urban growth, they rejected the expansive models that had been promoted but had become unfeasible. Eventually, these parties won the election in most important Spanish cities, including Valladolid, so they started to put their promises into practice, which involved the revision of general plans.

Beyond this reformist spirit, the new generation of general plans promoted by these new local governments assumed a 'dialectical relationship between structure and form, between structure and plan' (Calvo, 1990, p. 99). They looked for an integrated perspective combining two approaches: the parts defining

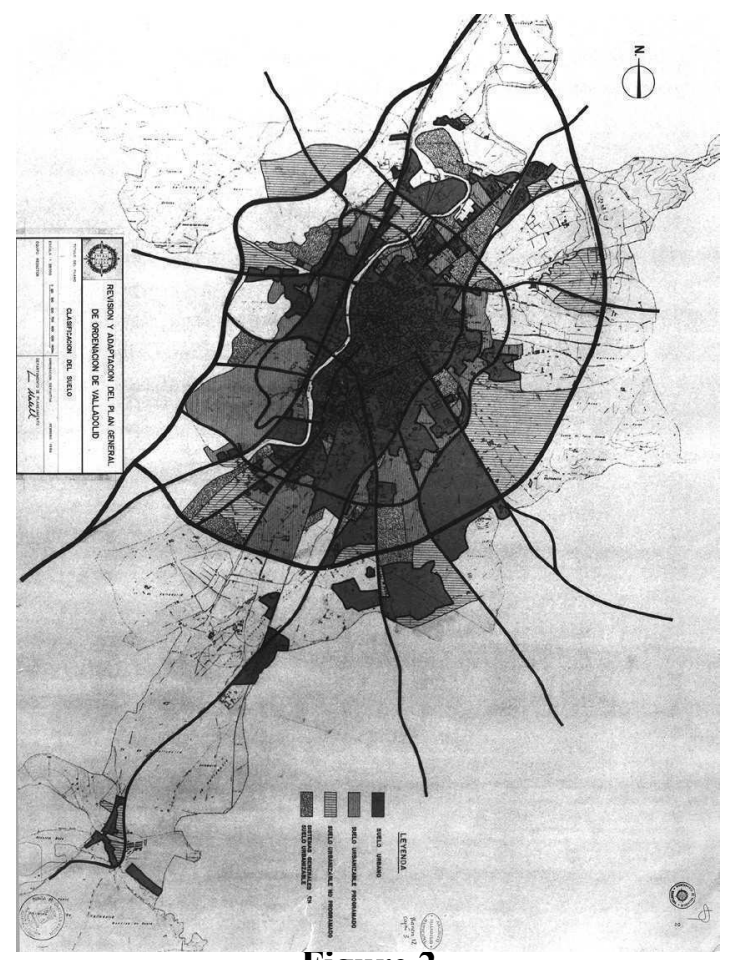

Figure 2.

General Plan of Valladolid, 1984.

General Structure and land classification.

the whole, and the whole defining the parts, i.e. they analysed and reflected on every part of the city so it would match the whole structure of the city, and they also checked that the addition of all parts would result in a balanced global structure. In this regard, they paid a particular attention to urban form at the intermediate scale, considering the existing city as the main reference and promoting its improvement in terms of reinforcing the coherence among the typologies, the network of streets and the planned or existing public spaces and buildings. All these features shared by most plans of that period were summarized by some authors under the expression of a 'more urban urbanism', so attached to the existing city that, in fact, 'the form of the city is the existing city itself, yet corrected and improved' (SoláMorales and Parcerisa, 1987, p. 50).

However, the problem of future urban growth had also to be faced. As the previous expansive models were considered excessive and unfitted to the existing city, the objective consisted of finding a model that would continue to be expansive but that would also allow the continuity with the existing city and even its improvement. While the most innovative 
effort concentrated on the re-definition of urban form within the existing city, the global urban structure was usually conceived from conservative schemes that had proved its efficiency, such as the radio-concentric ones. Aymonino (1981, p. 173-4) points that this scheme 'assumes a growth model based on a single political-administrative centre' and that it becomes 'the most suitable to foresee urban development - mainly composed of residential settlements -; indeed, these new sectors can be considered, within this scheme, as pieces to be added to a system that runs since preceding times $[\ldots]$ such as the system of the compact city'. Consequently, the radioconcentric model affirms the municipal power within metropolitan frameworks and it also sets the will to control urban growth, following this model of successive pieces that fit in a previously defined structure that emerges from the existing city and guarantees a continuity between what exists and what is planned. Valladolid and its new general plan, elaborated by a team headed by Bernardo Ynzenga and approved in 1984, are again a clear example.

This general plan aimed to get a 'spatially balanced and, specially, socially inclusive urban model, in contrast with the previous ones and assuming a radio-concentric spatial structure' (Fernández-Maroto 2015, p. 260). This radio-concentric scheme was composed of a double system of ring roads. The inner ring road was placed close to the existing periphery of the city, to fill in the spaces between it and this new road with new residential areas combined with public spaces to serve to both the existing and the planned neighbourhoods. Further away, the outer ring road defines a belt of residential sectors that would assume the urban growth in the long term and that define the final foreseen model of a compact city. However, this apparently isotropic scheme was altered by the effects of the metropolitan plan of 1970. Both ring roads are in fact uncomplete, as they connect with a motorway that follows the southwest direction that the metropolitan plan identified as the developing corridor to promote. Furthermore, the foreseen new residential sectors were to follow a programming that prioritized many located likewise in the southwest of the city. In fact, most of them were previous projects of local real estate developers that the new general plan decided to assume.

Thus, this general plan made use of traditional planning tools such as transport infrastructures or residential sectors to complete the existing neighbourhoods or 'pieces' of the city with additional future ones. All of them would remain embedded in a radio-concentric scheme that would guarantee a gradual and homogeneous growth towards a bigger but compact city. 'The costs of imposing to territory this apparently right conceptual form [...] seem here high' (Solá-Morales, 1985 , p. 11), but it was thought that the urban growth inertia towards the southwest could be controlled inside this scheme, and the illusion of a compact city prevailed. However, it turned soon into disillusion.

\section{The nineties: the emergence of an alternative model in a fragmented territory}

After the years of crisis, urban growth resumed from mid-eighties following economic

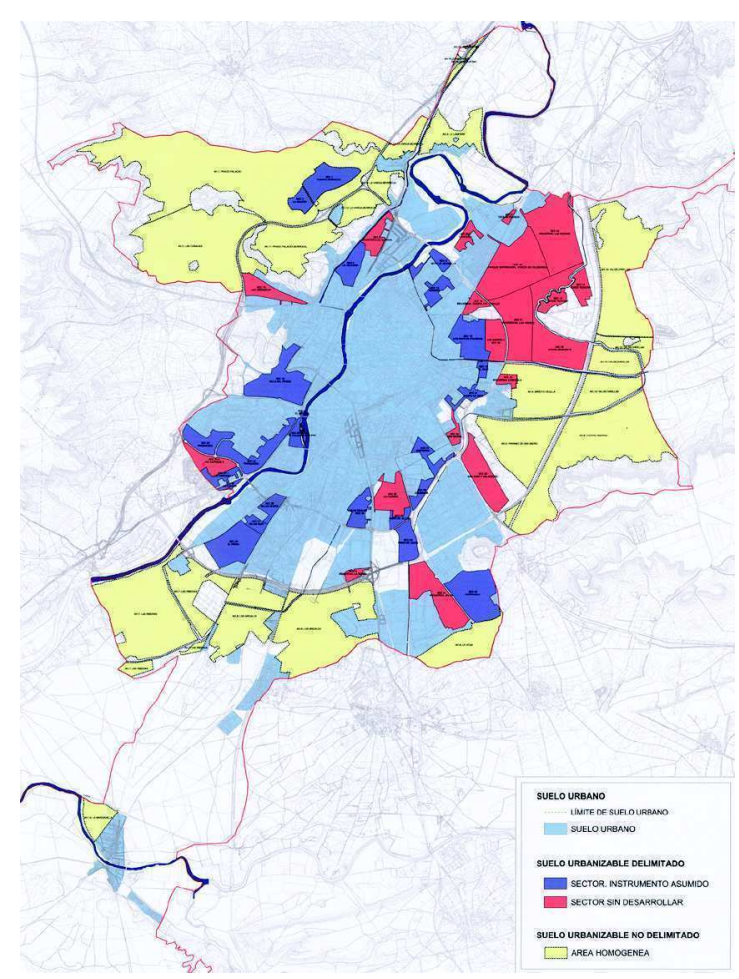

Figure 3.

General Plan of Valladolid, 2003. Land classification. 
development. Real estate market started a path of growth that briefly stopped between 1992 and 1993 but that progressively sped up since mid-nineties to the extent of generating a bubble that finally burst in 2008. As happened in the sixties and seventies, the role of real estate market in Spanish economy was fostered. First, investments were promoted through fiscal benefits. Later, actions related to urban law and practice were also taken. The Land Property and Urban Planning Act was reformed in 1998 to increase land offer to be urbanised, and municipal governments promoted the revision of general plans to put this policy into practice. Within this context, 'the question of urban planning, of the construction of the city, give in to the question of land, of the management of land market' (Roch Peña, 2001, p. 6). The concern on urban form and its cultural and social significance that existed in the eighties disappeared in practice.

In Valladolid, new residential sectors started to be developed from mid-eighties, all of them located in the south of the city. At the same time, some other municipalities close to this part of the city started to attract population that used to live in Valladolid, especially young people who found good dwellings at a better price than in the city. Ignoring the principle of territorial balance that the general plan approved in 1984 included, the municipal government of Valladolid reacted to this phenomenon and it promoted a complete new neighbourhood in the south of Valladolid after buying some land there. However, that action did not stop the move of people from the city to its surrounding municipalities, especially to those located in the southwest, the traditional and always promoted axis of development.

These surrounding municipalities had started to revise their general planning tools to increase the quantity of land to be urbanised and the municipal government of Valladolid decided eventually to employ the same strategy. The radio-concentric scheme that was defined in the eighties was driven out of the limits it was conceived with when a revision of the general plan was approved in 2003. Although numerous residential sectors that have been foreseen close to the existing city had not been developed, new ones were defined beyond the outer ring road, without thinking in a new scheme to assume that kind of expansion. It was a 'hyper-forecast of urban development $[\ldots]$ with no coherence regarding its strategical points' (Rivas Sanz, 2008, p. 289), a plan with no urban form, as spatial mechanisms are completely absent.

When real estate market fell down in 2008 , the consequences of this uncontrolled urban growth revealed themselves. Urban development had driven some parts of the city to a situation of congestion, with an excessive concentration of new residential zones, whereas some other parts became failed, as some zones were urbanised but not occupied, remaining half-empty. Emerging urban centralities were also bad managed, as several malls were promoted even though there was not enough demand to make them viable. This expansive urban model left behind a fragmented urban fringe, a condition that has been pointed as the main characteristic of contemporary cities, in opposition to 'the image of a regular, isotropic and infinite urban space, purified of any contingent character' (Secchi, 2004, p. 150). The kind of urban space that was foreseen

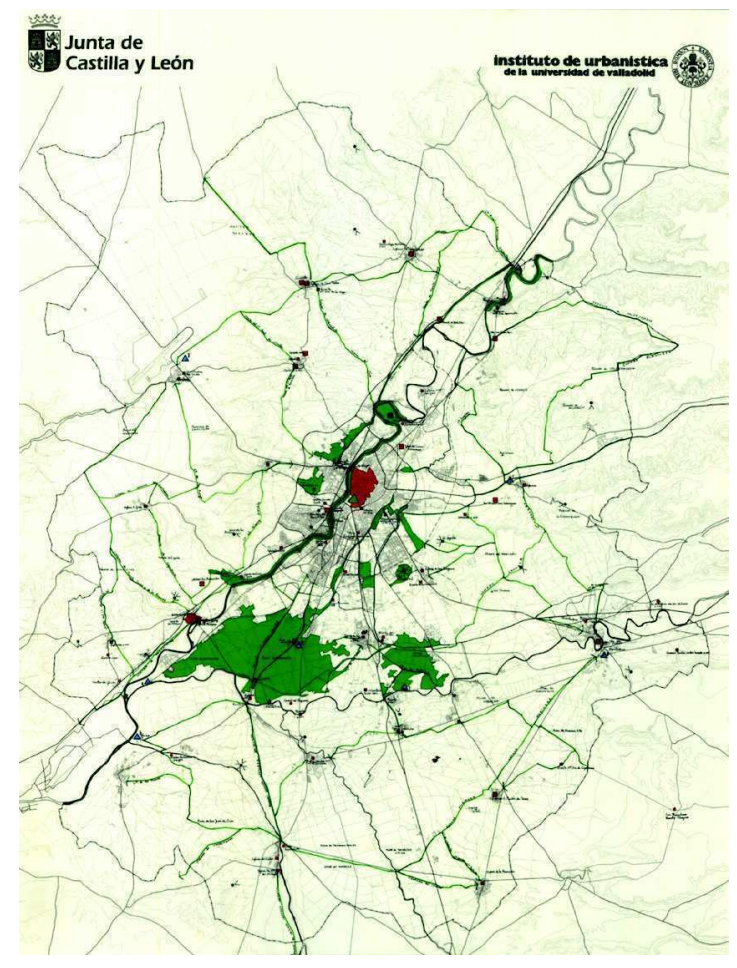

Figure 4.

Land Planning Guidelines for Valladolid, 2001. System of parks and green corridors. 
in the eighties and that revealed itself as unfeasible in the nineties. The question is then how to manage urban form within the context of the diffuse city.

In this regard, an alternative and more sustainable model had already emerged in Valladolid during the years of expansive growth. When the regional government of Castilla y León assumed competences in urban issues from mid-nineties, it approved a Territorial Planning Act that included new urban planning tools regarding metropolitan areas. Consequently, it commissioned the elaboration of the Land Planning Guidelines for Valladolid and its surrounding area, whose objective was to establish some criteria to manage urban growth without affecting the competences of municipal governments, which obviously constituted a great constraint. However, this new and innovative planning tool overcame this barrier by proposing a new perspective to define urban form at a metropolitan scale. The Land Planning Guidelines were not allowed to decide where to locate new urban areas, but they were allowed to prevent urban growth in those areas that merit a protection, due to its ecological or productive values. After thoroughly analysing the characteristics of the territory in the whole metropolitan area, the Land Planning Guidelines defined several spaces to be protected: the so-called Areas of Singular Ecological Value, which are the most important natural spaces, and the socalled Most Valuable Agrarian Landscapes, which are linked to historic infrastructures that had defined the structure of the territory. Furthermore, the Land Planning Guidelines proposed a metropolitan system of parks and green corridors to be 'the moderative key of dispersed growth and the guarantee of the positive quality of settlements system' (Rivas Sanz, 2010, p. 313).

Thus, they proposed a structure for the whole metropolitan area to be built upon a system of protected spaces and green corridors. Open spaces and the 'empty' network that would connect them emerged as the best way to define urban form in the context of the diffuse urban growth and the fragmented territory. They aimed at giving coherence to the whole urban structure in a metropolitan scale,

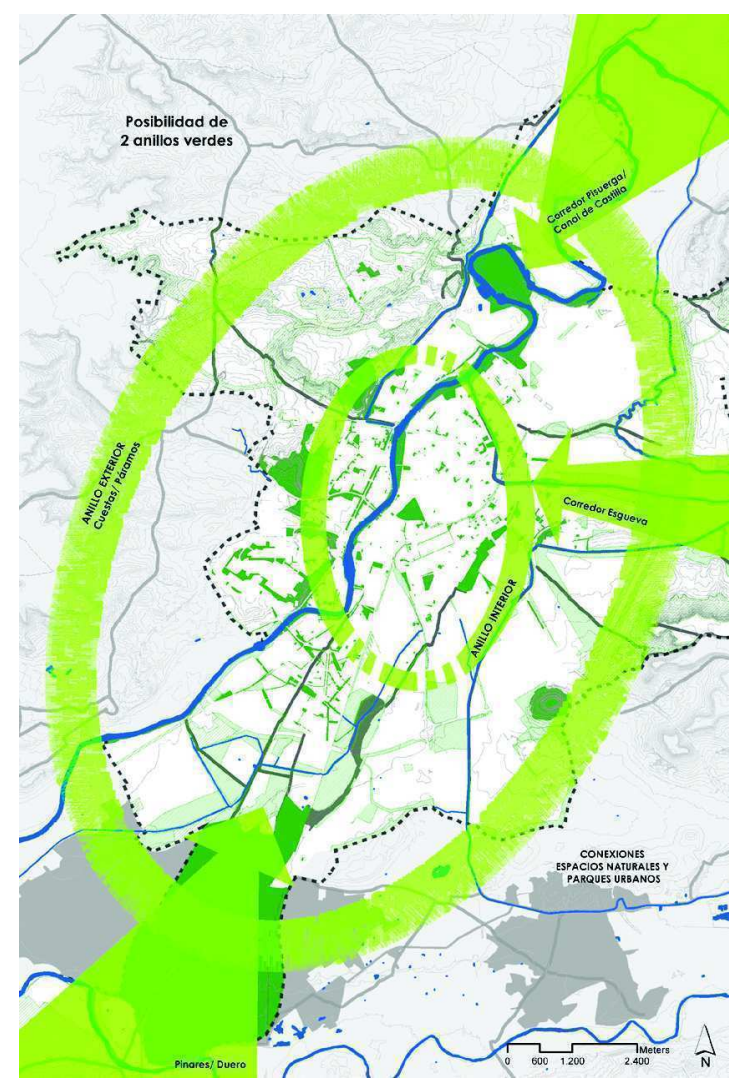

Figure 5.

General Plan of Valladolid (Advance), 2012. Scheme of inner and outer green belts

while the traditional mechanisms consisting of defining the zones to be urbanised were risking its sustainability.

\section{Conclusion}

Planning cities or metropolitan areas through an alternative system based on non-urbanised spaces and corridors is emerging as a more sustainable urban model. The process described in the case of Valladolid can also be found in other similar Spanish cities. For instance, the Accompanying Plan for the International Exhibition that took place in Zaragoza in 2008 proposed a network of green spaces related to various rivers and waterways. Gathering all reflections regarding this question that had been conducted for more than 15 years, this proposal aimed at giving coherence to the whole urban structure by guiding urban regeneration actions. The pioneering and most known case is Vitoria and its Green Belt, a comprehensive project for 
the whole periphery of the city that started in the eighties as a way to avoid floods and that later had to face expansive strains regarding new residential areas that put it at risk.

This kind of new urban networks is more and more related to a shift in city management summarised through the expression 'grey to green' (CABE, 2009), which means that traditional 'grey' urban infrastructures such as roads or canals can be substituted by more place-based, green mechanisms, which results in a more sustainable management of urban metabolism. However, it can also be read as a shift in urban form planning. In the context of the diffuse city, closed schemes employing these same 'grey' systems as planning mechanisms are not able to control urban growth, which is nowadays fragmented and depends on a multiplicity of decisions that are impossible to foresee. It is thus important to define an underlying scheme ensuring a more resilient and sustainable urban development.

The challenge consists of integrating this alternative model in usual urban planning, which continues to be very depending on those traditional mechanisms regarding the definition of future urban form. This new way is nevertheless little by little paved. After the bubble burst, Valladolid is now revising it general plan, and the advance document that was approved in 2012 to guide the revision proposed a new perspective on general urban form that is structured upon an inner and outer green belt. Following the spirit of the Land Planning Guidelines, these green belts are to assume the role of the inner and outer ring roads, which have been guiding urban form in the last thirty years.

\section{Acknowledgments}

The University of Valladolid has funded the attendance of the author to the 24th ISUF Valencia 2017 through the grant programme 'Movilidad Doctorandos UVa 2017'.

\section{References}

Aymonino, C. (1981) El significado de las ciudades (Blume, Madrid).

Doxiadis, C. A. (1963) Arquitectura en transición (Ariel, Barcelona).

Fernández Maroto, M. (2015) 'El Plan General de Valladolid de 1984. En los orígenes de un nuevo modelo urbano', Ciudades 18, 25563.

Figueroa Salas, J. (2000) La medida y la memoria: antología urbanística de Javier de Mesones 1950-2000 (Fundación Metrópoli, Madrid).

CABE (2009) Grey to green. How we shift funding and skills to green our cities (http:// www.designcouncil.org.uk/sites/default/ files/asset/document/grey-to-green.pdf) accessed 20 May 2017.

Calvo, L. (1990) 'El control del crecimiento urbano', in Instituto del Territorio y Urbanismo and Istituto Universitario di Architettura di Venezia, 10 años de planeamiento urbanístico en España 19791989 (Ministerio de Obras Públicas y Urbanismo, Madrid) 97-104.

Rivas Sanz, J. L. (2008) 'Ayuntamiento y urbanismo', in Merino Estrada, V. and Orduña Rebollo, E. (coord.) La ciudad de Valladolid y su Ayuntamiento: 100 años de historia común (Ayuntamiento de Valladolid, Valladolid) 271-94.

Rivas Sanz, J. L. (2010) 'La ordenación de los procesos metropolitanos: las directrices de ordenación territorial de Valladolid y de su entorno (2001)', in Vinuesa Angulo, J. and Galiana Martín, L. (ed.) Teoría y práctica para una ordenación racional del territorio (Síntesis, Madrid) 301-20.

Roch Peña, F. (2001) 'Hegemonía inmobiliaria y desregulación urbanística: el declive del Plan creador', Urban 6, 6-14.

Secchi, B. (2004) 'Ciudad moderna, ciudad contemporánea y sus futuros', in Martín Ramos, A. (ed.) Lo urbano en 20 autores contemporáneos (Edicions UPC, Barcelona) 145-58.

Solá-Morales, M. (1985) 'Valladolid: la constante reforma de crecer sobre sí misma', UR-Revista de Urbanismo 1, 2-19.

Solá-Morales i Rubió, M. and Parcerisa i Bundó, J. (1987) 'El urbanismo urbano: forma urbana y planeamiento urbanístico en siete capitales españolas', Estudios 
Territoriales 24, 33-51.

Terán, F. (1982) Planeamiento urbano en la España contemporánea $(1900 / 1980)$ (Alianza, Madrid).

Whitehand, J.W.R. (2001) 'British urban morphology: the Conzenian tradition', Urban Morphology 5(2), 103-9. 